\title{
Two novel adenoviruses found in Cave Myotis bats (Myotis velifer) in Oklahoma
}

\author{
Dana N. Lee ${ }^{1} \cdot$ Meagan Angiel ${ }^{1}$
}

Received: 27 July 2019 / Accepted: 25 November 2019 / Published online: 3 December 2019

๑) Springer Science+Business Media, LLC, part of Springer Nature 2019

\begin{abstract}
Bats are carriers of potentially zoonotic viruses, therefore it is crucial to identify viruses currently found in bats to better understand how they are maintained in bat populations and evaluate risks for transmission to other species. Adenoviruses have been previously detected in bats throughout the world, but sampling is still limited. In this study, 30 pooled-guano samples were collected from a cave roost of Myotis velifer in Oklahoma. A portion of the DNA polymerase gene from Adenoviridae was amplified successfully in $18 \mathrm{M}$. velifer samples; however, DNA sequence was obtained from only 6 of these M. velifer samples. One was collected in October 2016, one in March 2017, and 4 in July 2017. The October and March samples contained viral DNA that was 3.1\% different from each other but 33\% different than the novel viral sequence found in the July 2017 samples. Phylogenetic analysis of these fragments confirmed our isolates were from the genus Mastadenovirus and had genetic diversity ranging from 20 to $50 \%$ when compared to other bat adenoviruses.
\end{abstract}

Keywords Adenovirus $\cdot$ Bat $\cdot$ Myotis $\cdot$ Mastadenovirus

Bats make up $20 \%$ of all mammals, and they are the second richest mammalian order in respect to number of species $[1,2]$. In recent years, bats have emerged as a rich source of novel viruses $[3,4]$. They have been found to host more zoonotic viruses per species than rodents [5], and even documented to harbor viruses from two different viral families simultaneously [6]. Viruses in bats can switch hosts to other bat species [4] and they are known to carry pathogenic viruses that can infect humans such as rabies, lyssaviruses, nipah and hendra viruses, ebola, and SARS coronavirus [7, 8]. However, in most cases bats serve as reservoirs for viruses with immunological tolerance and without transmission to other humans [7,9]. Consequently, it is important to first identify viruses housed in bats in order to better understand the ecology of bat-borne viruses, how they are maintained in bat populations, and then evaluate risks for host transmission to other species.

Edited by Takeshi Noda.

Dana N. Lee

dalee@cameron.edu

1 Department of Agriculture, Biology \& Health Sciences, Cameron University, 2800 W. Gore Blvd, Lawton, OK 73505, USA
Adenoviruses (AdVs) are double stranded DNA viruses found in vertebrate hosts of many different species [8, 10]. The family Adenoviridae consists of five genera [11] with members in the genus Mastadenovirus infecting mammals [12]. AdVs are widespread in the human population and cause a variety of usually minor symptoms, such as respiratory illnesses, conjunctivitis, and gastroenteritis [8]. Generally, these viruses are host-specific [13] and thought to have low zoonotic risk [14]; however, Chen et al. [15] discovered a novel adenovirus (TMAdV) with the ability to infect both monkeys and humans. Since bats are known reservoirs of numerous viruses and cross-species transmission has been documented for an $\mathrm{AdV}$, it will be useful to know which AdVs bats carry. AdV strains have been found in more than 45 species of bats across their global distribution $[6,8,12$, 16-34] with seven species proposed by the International Committee on Taxonomy of Viruses [35]. These studies represent a start at investigating bat $\mathrm{AdVs}$, but there is a need for additional studies considering there are over 1300 species of bats [2] and few North American bats have been investigated.

In this study, Myotis velifer guano samples were tested for the presence of AdVs. We expected to find AdVs in $M$. velifer because that genus had the most AdVs in a study on 19 bat species in China [8]. Guano was collected from $M$. 
velifer individuals in Washita Bat Cave (Washita Co, OK). Samples were either collected from a plastic tarp left laying overnight at the entrance of the cave (in March or July) or after bats were captured and placed in a sterile cup for $1 \mathrm{~h}$ (in October). Bats were handled following guidelines from Sikes et al. [36], and white nose syndrome decontamination protocols were followed [37]. Regardless of method of collection, four guano pellets were stored collectively in $500 \mu \mathrm{l}$ of RNA Later ${ }^{\circledR}$, and stored at $-20^{\circ} \mathrm{C}$. We obtained a total of 120 guano pellets and this provided 30 pooled samples for analysis.

DNA extraction was carried out with QIAamp ${ }^{\circledR}$ DNA Mini Kit (Qiagen) following the manufacture's protocol with minor modifications. Nested PCR of the partial Adenoviridae DNA polymerase gene was carried out on each sample following Li et al. [8] using primers pol-F (5' CAGCCKCKGTTRTGYAGGGT 3') and pol-R (5' GCHACCATY AGCTCCAACTC $3^{\prime}$ ). Cycling profile consisted of $94^{\circ} \mathrm{C}$ for $5 \mathrm{~min}, 30$ cycles of $94{ }^{\circ} \mathrm{C}$ for $30 \mathrm{~s}, 48^{\circ} \mathrm{C}$ for $30 \mathrm{~s}, 72{ }^{\circ} \mathrm{C}$ for $30 \mathrm{~s}$, and then a final extension of $72^{\circ} \mathrm{C}$ for $5 \mathrm{~min}$. The second round of amplification used $1 \mu \mathrm{l}$ of first round PCR product as template, primers pol-nf (5' GGGCTCRTTRGT CCAGCA $3^{\prime}$ and pol-nr (5' TAYGACATCTGYGGCATGTA $3^{\prime}$ ) and the same cycling steps. Positive (Human Adenovirus D DNA from American Type Culture Collection) and negative controls were used for each PCR. Positive PCR products were purified with Wizard ${ }^{\circledR}$ SV Gel and PCR Clean-up System (Promega). Species verification of bats with positive AdV samples was performed using nested PCR with primers SFF_145f (5' GTHACHGCYCAYGCHTTYGTAATAAT $3^{\prime}$ ) and SFF_351r (CTCCWGCRTGDGCWAGRTTTCC 3') from [38] and thermocycler steps consisting of $95^{\circ} \mathrm{C}$ for $5 \mathrm{~min}, 38$ cycles of $95^{\circ} \mathrm{C}$ for $60 \mathrm{~s}, 60^{\circ} \mathrm{C}$ for $30 \mathrm{~s}, 72^{\circ} \mathrm{C}$ for $30 \mathrm{~s}$, and final extension of $72{ }^{\circ} \mathrm{C}$ for $10 \mathrm{~min}$ to amplify a region of the cytochrome $\mathrm{c}$ oxidase gene that is highly diagnostic among bats.

Sanger sequencing of positive samples for bat and AdV identification was performed by Oklahoma Medical Research Foundation, and fragments were aligned and manually edited in Geneious v. 10.1.3 [39]. AdV sequences (131) isolated from other bat species, turkey, canine, bovine, and human AdVs A, B, C, and D on GenBank were added to the final alignment. Model of sequence evolution, maximum likelihood analysis, and uncorrected $\mathrm{P}$ nucleotide distance were performed in Mega v. 7.0.26 using all sites, including gaps, and 1000 bootstrap replicates [40].

There was at least one positive sample for each collection date, but only 6 of 18 positive samples had viral DNA quantities necessary for successful sequencing. The alignment of our DNA sequences with only the recognized viral species followed a Hasegawa-Kishino-Yano model of evolution with a gamma distribution of 0.4847 . The maximum likelihood analysis indicated that the Advs were of the
Mastadenovirus genus and our proposed AdVs form separate clusters in distinct clades (Fig. 1). When all sequences from GenBank were included in the alignment the model of nucleotide evolution was the General Time Reversible model with a gamma distribution of 0.6376 and invariant sites. In this analysis (not shown), the AdV sequences did not form clusters according to their host family. This suggests transmission between host species is more common than coevolution with the host.

Myotis velifer samples from October 2016 (Guano 61) and March 2017 (Guano 2) were only 3.1\% different from each other, while they were $\sim 33 \%$ different from the 4 sequences extracted from July 2017 samples (Guano 21, 22, 24, 25). Guano 21 was identical to Guano 22 and 24, and it was only 1 nucleotide different than Guano 25. DNA sequences from Guano 2, 61, and 21 have been deposited in GenBank (Accession MN240005-MN240007). We do recognize the sequenced fragment is short (241 basepairs) and only provides preliminary viral classification. AdVs species are designated if amino acid sequence is $>5 \%$ for the DNA polymerase gene. Based on this criterion, we suggest Guano 61 and Guano 2 are different strains of the same AdV species and are further referred to as Cave Myotis AdV1-1 and Cave Myotis AdV1-2. DNA sequence from Guano sample 21, 22, 24, and 25 represent a separate Adenovirus species and are further referred to as Cave Myotis AdV2. There were 2 non-synonymous mutations and 2 synonymous mutations between Cave Myotis AdV1-1 and AdV1-2. Cave Myotis AdV1-1 and AdV1-2 are most similar to GU226951 isolated from Myotis horsfieldii [8] with genetic differences of $21.7 \%$ and $23.3 \%$, respectively, and most different from HQ529709 isolated from Rousettus leschenaultii [21] with genetic differences of 48.45 and $49.2 \%$, respectively. Cave Myotis AdV2 is most similar to MF404977, 80-82, 84-87 isolated from Pipistrellus pygmaeus [32] with a genetic difference of $20.2 \%$. Cave Myotis AdV2 is most different from KC692424, 28 isolated from Pteropus giganteus [24] and HQ529709 isolated from R. leschenaultii [21] by $44.5 \%$. These two new AdVs are $\geq 27 \%$ different than any currently recognized bat mastadenovirus A-G (Table 1). When AdV sequences were compared to other AdVs from bats, genetic diversity ranged from 20 to $50 \%$. This study demonstrates that there is great genetic diversity of DNA viruses within the same species of bats found in the same location, which is relatively uncommon for other vertebrate viruses [8].

We sampled caves during 3 seasons and found greater prevalence of viral DNA in $M$. velifer guano during summer (July; 14/16 samples $=87 \%)$ than spring (March; 1/4 samples $=25 \%$ ) or autumn (October; $3 / 10$ samples $=30 \%$ ). This is the highest percentage of positive Adv samples detected in bats to date from a single sampling period. Drexler et al. [20] collected guano samples from M. myotis in Germany during May, June, and July for 3 years, and the highest percentage 


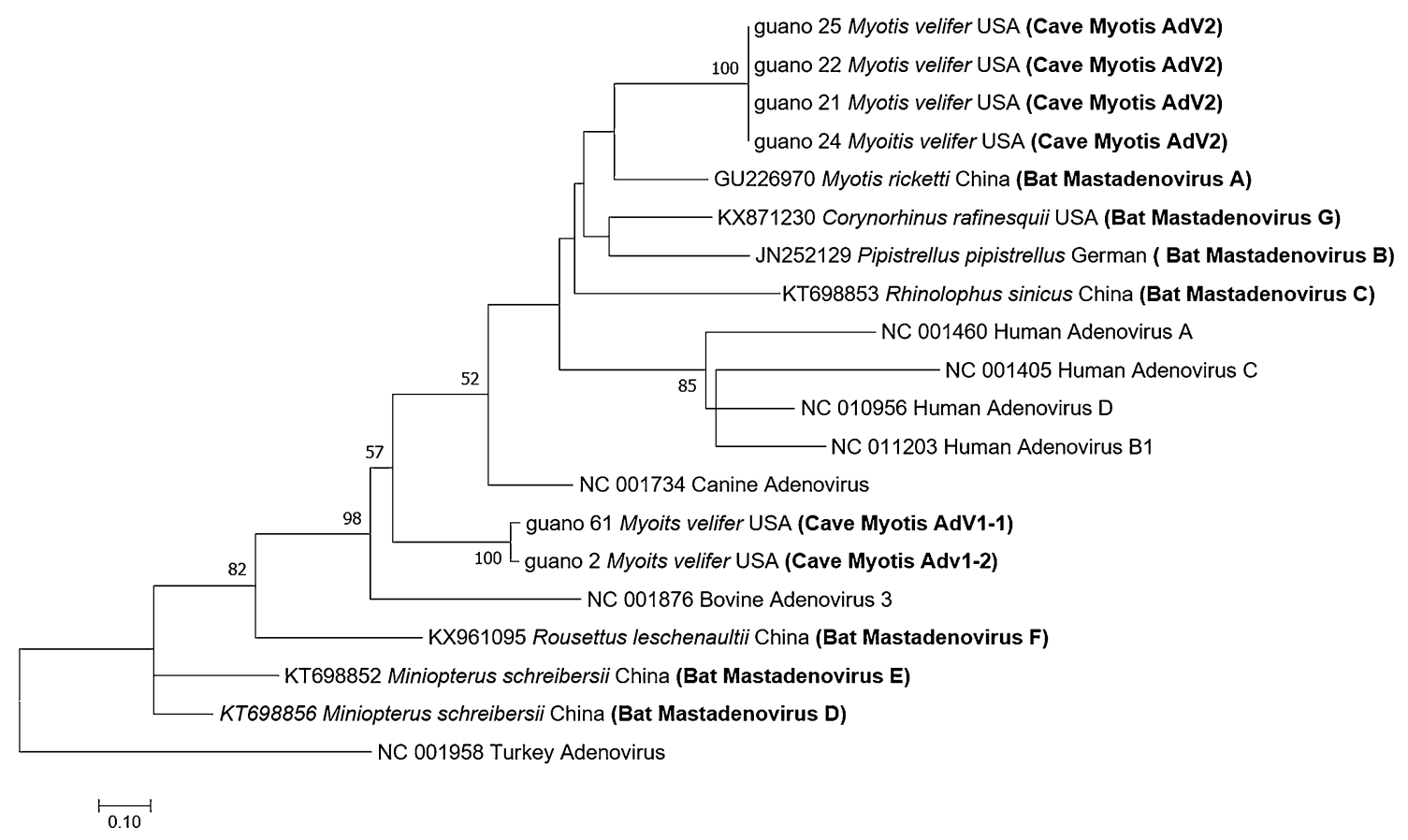

Fig. 1 Phylogenetic relationships of novel bat viruses and described bat mastadenovirus sequences available on GenBank. Maximum likelihood phylogeny was generated in MEGA7 using a 241-bp fragment of the DNA polymerase gene. Tree was inferred using the Hasegawa-
Kishino-Yano G+I model and 1000 bootstrap replicates. Values $>50$ indicated for nodal support. Sequences obtained in this study named with the proposed AdV strain
Table 1 Percent nucleotide difference between strains of bat mastadenovirus isolated from Myotis velifer and recognized bat mastadenovirus species based on the 241-bp fragment of DNA polymerase gene

\begin{tabular}{llllll}
\hline $\begin{array}{l}\text { Strain of bat } \\
\text { mastadeno- } \\
\text { virus }\end{array}$ & Bat species & GenBank ID & $\begin{array}{l}\text { Cave Myotis } \\
\text { AdV1-1 }\end{array}$ & $\begin{array}{l}\text { Cave Myotis } \\
\text { AdV1-2 }\end{array}$ & $\begin{array}{l}\text { Cave } \\
\text { Myotis } \\
\text { AdV2 }\end{array}$ \\
\hline A & Myotis ricketti & GU226970 [8] & 32.6 & 33.3 & 27.1 \\
B & Pipistrellus pipistrellus & JN252129 [17] & 34.1 & 36.4 & 28.9 \\
C & Rhinolophus sinicus & KT69853 [28] & 35.7 & 35.7 & 28.6 \\
D & Miniopterus schreibersii & KT698856 [12] & 40.2 & 41.7 & 40.2 \\
E & Miniopterus schreibersii & KT698852 [12] & 43.3 & 43.3 & 44.1 \\
F & Rousettus leschenaultia & KX961095 [12] & 36.6 & 36.6 & 36.6 \\
G & Corynorhinus rafinesquii & KX871230 [29] & 32.6 & 32.6 & 28.7 \\
\hline
\end{tabular}

Genetic difference values estimated in Mega7 of positive samples for 1 sample date $(67.5 \%, 27 / 40$ samples) was collected in May and the same frequency in July. It is likely our high percentage of positive samples from one sample date is because $M$. velifer give birth to their young in May-June [41]. In summer there are many young bats present with weaker immune systems and a greater risk of lactating females sharing viruses with their young. Drexler et al. [20] found a significant increase in prevalence of coronaviruses one month after parturition during summer months but AdV detection was not significantly higher in any particular month within in the summer.

Little work has been done to investigate AdVs in North American species of bats; however, these studies [19, 29] and ours highlight the importance of identifying viruses housed in bats to better understand viral evolution, how viruses are maintained in bat colonies and evaluate risks for host transmission to other species. Li et al. [8] found their novel bat AdV (BtAdV-TJM) was capable of infecting several mammalian cells from different species, including humans, which indicates that bat AdVs possibly have a wide host range. They also suggest some bat AdVs have similar amino acid sequences for structural proteins to those in human AdVs and a high GC content, which suggest bat AdVs might be an ideal vector for gene therapy and vaccine delivery in humans [8]. Future studies should include sequencing the entire viral genomes and isolating the viruses 
to test possible transfections in other species to better characterize the viruses discovered here.

Acknowledgements We thank Jason Shaw, Bill Caire, Linda Loucks and Lyrics Goins for sample collection and a private landowner for access to Washita Cave. Financial support provided by the Agriculture, Biology, and Health Sciences Department and a Cameron University Research Grant awarded to Dana N. Lee.

Author contributions DNL and MA have contributed to data collection, analysis, and writing the manuscript.

\section{Compliance with ethical standards}

Conflict of interest The authors declare that they have no conflict of interest.

Ethical approval All applicable national guidelines for the care and use of animals were followed.

\section{References}

1. Simmons NB (2005) Order Chiroptera. In: Wilson D, Reeder D (eds) Mammal species of the world: a taxonomic and geographic reference. Johns Hopkins University Press, Baltimore, pp 312-529

2. Burgin CJ, Colella JP, Kahn PL, Upham NS (2018) How many species of mammals are there? J Mammal 99:1-14

3. Young CC, Olival KJ (2016) Optimizing viral discovery in bats. PLoS ONE 11(2):e0149237

4. Willoughby AR, Phelps KL, PREDICT Consortium, Olival KJ (2017) A comparative analysis of viral richness and viral sharing in cave-roosting bats. Diversity. https://doi.org/10.3390/d9030035

5. Luis AD, Hayman DTS, O'Shea TJ, Cryan PM, Gilbert AT, Pulliam JRC, Mills JN, Timonin ME, Willis CKR, Cunningham AA, Fooks AR, Rupprecht CE, Wood JLN, Webb CT (2013) A comparison of bats and rodents as reservoirs of zoonotic viruses: are bats special? Proc R Soc B 280:20122753

6. Conrardy C, Tao Y, Kuzmin IV, Niezgoda M, Agwanda B, Breiman RF, Anderson LJ, Rupprecht CE, Tong S (2014) Short report: molecular detection of adenoviruses, rhabdoviruses, and paramyxoviruses in bats from Kenya. Am J Trop Med Hyg 91:258-266

7. Calisher CH, Childs JE, Field HE, Holmes KV, Schountz T (2006) Bats: important reservoir hosts of emerging viruses. Clin Microbiol Rev 19:531-545

8. Li Y, Xingyi G, Huajun Z, Peng Z, Yan Z, Yunzhi Z, Junfa Y, Lin-Fa W, Zhengli S (2010) Host range, prevalence, and genetic diversity of adenoviruses in bats. J Virol 84:3889-3897

9. Brook CE, Dobson AP (2015) Bats are "special" reservoirs for emerging zoonotic pathogens. Trends Microbiol 23:172-180

10. Kohl C, Vidovszky MZ, Muhldorfer K, Dabrowski PW, Radonic A, Nitsche A, Wibbelt G, Kurth A, Harrach B (2011) Genome analysis of bat adenovirus 2: indications of interspecies transmission. J Virol 86(3):1888-1892

11. Harrach B, Benkő M, Both GW, Brown M, Davison AJ, Echavarría M, Hess M, Jones MS, Kajon A, Lehmkuhl AD, Mautner V, Mittal SK, Wadell G (2011) Family Adenoviridae. In: King AMQ, Adams MJ, Carstens EB, Lefkowitz EJ (eds) Virus taxonomy: classification and nomenclature of viruses.
Ninth Report of the International Committee on Taxonomy of Viruses, Elsevier, San Diego, pp 125-141

12. Tan B, Xing-Lou Y, Xing-Yi G, Cheng P, Hai-Zhou L, Yun-Zhi Z, Li-Biao Z, Zheng-Li S (2017) Novel bat adenoviruses with low $\mathrm{G}+\mathrm{C}$ content shed new light on the evolution of adenoviruses. J Gen Virol 98:739-748

13. Benkő M, Harrach B (2003) Molecular evolution of Adenoviruses. Curr Top Microbiol Immunol 272:3-35

14. Benkő M, Harrach B, Kremer EJ (2014) Do nonhuman primate or bat adenoviruses pose a risk for human health? Future Microbiol 9:269-272

15. Chen EC, Yagi S, Kelly KR, Mendoza SP, Maninger N, Rosenthal A, Spinner A, Bales KL, Schnurr DP, Lerche NW, Chiu CY (2011) Cross-species transmission of a novel adenovirus associated with a fulminant pneumonia outbreak in a New World monkey colony. PLoS Pathog 7:1-16

16. Maeda K, Hondo E, Terakawa J, Kiso Y, Nakaichi N, Endoh D, Sakai K, Morikawa S, Mizutani T (2008) Isolation of novel adenovirus from fruit bat (Pteropus dasymallus yayeyame). Emerg Infect Dis 14:347-349

17. Sonntag M, Muhldorfer K, Speck S, Wibbelt G, Kurth A (2009) New adenovirus in bats, Germany. Emerg Infect Dis 15:2052-2055

18. Jánoska M, Vidovszky M, Molnar V, Liptovszky M, Harrach B, Benko M (2011) Novel adenoviruses and herpesviruses detected in bats. Vet $\mathrm{J}$ 189:118-121

19. Li L, Victoria JG, Wang C, Jones M, Fellers GM, Kunz TH, Delwart E (2010) Bat guano virome: predominance of dietary viruses from insects and plants plus novel mammalian viruses. J Virol 84:6955-6965

20. Drexler JF, Corman VM, Wegner T, Tateno AF, Zerbinati RM, Gloza-Rausch F, Seebens A, Muller MA, Drosten C (2011) Amplification of emerging viruses in a bat colony. Emerg Infect Dis 17:449-456

21. Raut CG, Yadav PD, Towner JS, Amman BR, Erickson BR, Cannon DL, Sivaram A, Basu A, Nichol ST, Mishra AC, Mourya DT (2012) Isolation of a novel adenovirus from Rousettus leschenaultia bats from India. Intervirology 55:488-490

22. Vidovszky MZ, Boldogh S (2011) Detection of adenoviruses in the northern Hungarian bat fauna. Hungarian Vet J 133:747-753

23. Chen LH, Wu ZQ, Hu YF, Yang J, Jin Q (2012) Genetic diversity of adenoviruses in bats of China. Chinese J Virol 28:403-408

24. Anthony SJ, Epstein JH, Murray KA, Navarrete-Macias I, Zambrana-Torrelio CM, Solovyov A, Ojeda-Flores R, Arrigo NC, Islam A, Khan SA, Hosseini P, Bogich TL, Olival KJ, SanchezLeon MD, Karesh WB, Goldstein T, Luby SP, Morse SS, Mazet JAK, Daszak P, Lipkin WI (2013) A strategy to estimate unknown viral diversity in mammals. MBio 4:e00598-13.

25. Baker KS, Leggett RM, Bexfield NH, Alston M, Daly G, Todd S, Tachedjian M, Homes CEG, Crameri S, Wang L, Heeney JL, Suu-Ire R, Kellam P, Cunningham AA, Wood JLN, Caccamo M, Murcia PR (2013) Metagenomic study of the viruses of African straw-coloured fruit bats: detection of a chiropteran poxvirus and isolation of a novel adenovirus. Virology 441:95-106

26. Lima EF, Cibulski SP, Elesbaco F, Carnieli Jr P, Batista HB, Roehe PM, Franco AC (2013) First detection of adenovirus in the vampire bat (Desmodus rotundus) in Brazil. Virus Genes 47:378-381

27. Vidovszky MZ, Kohl C, Boldogh S, Gorfol T, Wibbelt G, Kurth A, Harrach B (2015) Random sampling of the central European bat fauna reveals the existence of numerous hitherto unknown adenoviruses. Acta Vet Hung 63:508-525

28. Tan B, Yang XL, Ge XY, Peng C, Zhang YZ, Zhang LB, Shi ZL (2016) Novel bat adenoviruses with an extremely large E3 gene. J Gen Virol 97:1625-1635 
29. Hackenbrack N, Rogers MB, Ashley RE, Keel MK, Kubiski SV, Bryan JA, Ghedin E, Holmes EC, Hafenstein SL, Allison AB (2017) Evolution and cryo-electron microscopy capsid structure of a North American Bat Adenovirus and its relationship to other Mastadenoviruses. J Virol 91:e01504-e1516

30. Han HJ, Wen HL, Zhao L, Liu JW, Lou LM, Zhou CM, Qin XR, Zhu YL, Liu MM, Qi R, Li WQ, Yu H, Yu XJ (2017) Novel coronaviruses, astroviruses, adenoviruses and circoviruses in insectivorous bats from northern China. Zoonoses Public Health 64:636-646

31. Geldenhuys M, Mortlock M, Weyer J, Bezuidt O, Seamark ECJ, Kearney T, Gleasner C, Erkkila TH, Cui H, Markotter W (2018) A metagenomic viral discovery approach identifies potential zoonotic and novel mammalian viruses in Neoromicia bats within South Africa. PLoS ONE 13(3):e0194527

32. Iglesias-Caballero M, Juste J, Vázquez-Móron S, Falcon A, AznarLopez C, Ibáñez C, Pozo F, Ruiz G, Bercian JM, Garin I, Aihartza J, Echevarría JE, Casas I (2018) New adenovirus groups in western palearctic bats. Viruses. https://doi.org/10.3390/v10080443

33. Waruhiu C, Ommeh S, Obanda V, Agwanda B, Gakuya F, Ge XY, Yang XL, Wu LJ, Zohaib A, Hu B, Shi ZL (2017) Molecular detection of viruses in Kenyan bats and discovery of novel astroviruses, caliciviruses, and rotaviruses. Virol Sin 32:101-114

34. Liang J, Yang XL, Li B, Liu Q, Zhang Q, Liu H, Kan HP, Wong KC, Check SN, He X, Peng X, Shi ZL, Wu Y, Zhang L (2017) Detection of diverse viruses in alimentary specimens of bats in Macau. Virol Sin 32:226-234

35. Diakoudi G, Lanave G, Moreno A, Chiapponi C, Sozzi E, Prosperi A, Larocca V, Losurdo M, Decaro N, Martella V, Lavazza A, Lelli D (2019) Surveillance for adenoviruses in bats in Italy. Viruses $11: 523$
36. Sikes RS, Gannon WL (2011) Guidelines of the American Society of Mammalogists for the use of wild mammals in research. $\mathbf{J}$ Mammal 92(1):235-253

37. White-Nose Syndrome Response Team (2018). National whitenose syndrome decontamination protocol. https://s3.amazonaws. com/org.whitenosesyndrome.assets/prod/7a93cc80-b785-11e887bb-317452edc988-National_WNS_Decon_UPDATE_09132 018.pdf Accessed 5 March 2019

38. Walker FM, Williamson CHD, Sanchez DE, Sobek CJ, Chambers CL (2016) Species from feces: Order-wide identification of Chiroptera from guano and other non-invasive genetic samples. PLoS ONE 11:1-22

39. Kearse M, Moir R, Wilson A, Stones-Havas S, Cheung M, Sturrock S, Buxton S, Cooper A, Markowitz S, Duran C, Thierer T, Ashton B, Mentjies P, Drummond A (2012) Geneious basic: an integrated and extendable desktop software platform for the organization and analysis of sequence data. Bioinformatics 28:1647-1649

40. Kumar S, Stecher G, Tamura K (2015) MEGA7: Molecular evolutionary genetics analysis version 7.0. Mol Biol Evol 33:1870-1874

41. Ammerman LK, Hice CL, Schmidly DJ (2012) Bats of Texas. Texas A\&M University Press, College Station TX

Publisher's Note Springer Nature remains neutral with regard to jurisdictional claims in published maps and institutional affiliations. 